\title{
THE EFFECTS OF HYDROXYAPATITE AND PLATELET RICH PLASMA ON APEXOGENESIS IN MONKEYS
}

\author{
PETROVIĆ VANJA*, DANILOVIĆ VESNA*, MARKOVIĆ D*, ČAKIĆ S*, KRSTIĆ N** \\ and MARKOVIĆ DANICA** \\ *Faculty of Stomatology, Belgrade; **Faculty of Veterinary Medicine, Belgrade \\ (Received 1. February 2009)
}

There are very few data about the effects of endogenous growth factors in vital pulp therapy, and still they are often controversial. This study was undertaken with the aim to evaluate the effects of platelet rich plasma (PRP) in conjugation with hydroxyapatite (HAP), as pulp capping materials, on root and periodontium formation. Eight young monkeys (Cercopithecus Aethiops) with permanent dentition and incomplete root formation were involved in this study. After pulpotomy, the pulp lesion was capped with calcium hydroxide (control), HAP (experimental) or HAP in conjugation with PRP (experimental). Six moths later, the animals were sacrificed, the tissue was removed en block, and prepared for histological analysis in a routine way. The results of histological analysis revealed that the healing process, characterized by dentin bridge formation, maintained morphological and functional integrity of dental pulp and complete formation of dental root and surrounding periodontium. The inflammatory reaction was scored as mild to moderate, in almost all samples in all groups, suggesting the biocompatibility of the used materials. Materials used in this study are convenient as capping agents, contributing in maintaining the integrity of the pulp tissue and facilitating root and periodontium formation. According to histological data it could be suggested that hydroxyapatite in conjugation with endogenous growth factors, represent a superior alternative to other materials used in this study.

Key words: apexogenesis, histology, HAP, PRP

\section{INTRODUCTION}

Traumatic injuries to young permanent teeth are not uncommon and are said to affect $30 \%$ of children (Andreasen, 1994). The majority of these incidents occurs before root formation is complete and may result in pulp inflammation or necrosis (Andreasen et al., 2002). A healthy pulp is generally regarded as essential for proper formation of the root in a developing tooth. Hertwig's root sheath, provided that it is not injured or infected, due to the presence of a large 
number of undifferentiated cells and blood vessels is able to contribute to the formative cells proliferation and differentiation and have an influence on root development (Rafter, 2005). The role of Hertwig epithelial sheet in root development is complex. It is thought to provide a source of undifferentiated cells that could differentiate into formative cells important in hard tissue formation. It may also serve as a barrier that protects against the ingrowths of periodontal ligament cells into the root canal, which could result in intracanal bone formation and arrest of root development (Webber, 1984). Because of the important role of the epithelial root sheath of Hertwig in continued root development after pulp injury, every effort should be made to maintain its viability.

Webber (1984) suggested that a favorable treatment outcome and completion of formation of the root and surrounding periodontal tissue may be expected only if integrity of the pulp and existing odontoblasts, responsible for the formation of reparative dentine and closure of pulp chamber, is preserved. The process of reparative dentinogenesis is additionally confused by the fact that it includes whether primary odontoblasts or odontoblasts-like cells, which are also capable to secrete extracellular matrix and to initialize it's mineralization, in that way making dentine-like tissue (Gronthos et al., 2002). Following mechanical exposure of the pulp irreversible damage of primary odontoblasts usually occurs. These cells, as postmitotic terminally differentiated cells, have no possibility to proliferate to replace irreversibly damaged odontoblasts. The origin of odontoblast-like cells, which produce the dentin bridge following pulp exposure, has provided to be controversial. Recent attention has focused on undifferentiated mesenchymal cells, associated with pulp vascularisation, most probably pericytes or pericytes progenitor cells such are myofibroblasts (AlliottLicht et al., 2001). The mechanism by which pulp cells differentiate into odontoblast-like cells and secrete the dentin bridge in the absence of the basement membrane or dental epithelium are not fully understood (Tzifas, 2004).

Growth factors are biological mediators which control processes of tissue reparation, including cell proliferation, differentiation, synthesis of extracellular matrix and angiogenesis. Apart from taking part in haemostasis and inflammation, platelets contribute in the reparation of mineralized and soft tissues. Alpha granules have numerous growth factors such are platelet-derived growth factor (PDGF), transforming growth factor $\beta$ (TGF- $\beta$ ), insulin-like growth factor (IGF), epidermal growth factor (EGF) and others (Gentry, 1992). Previous studies have shown that local application of platelet rich plasma (PRP) may be a superior alternative to the local application of growth factors only in achieving reparatory processes (Kim et al., 2002).

The influence of PRP on cell differentiation and proliferation is better examined at in vitro conditions, although the results are often controversial (Kilian et al., 2004; Kanno et al., 2005; Graziani et al., 2006). Some clinical studies indicated that the use of PRP has positive effects on the reparatory processes (Mazor et al., 2004), while others failed to show these effects (Froum et al., 2002). Such controversial results may be explained by different methods of preparation, and, consequently, different concentrations of PRP. It is still not clear which 
Acta Veterinaria (Beograd), Vol. 59. No. 2-3, 277-289, 2009.

Petrović Vanja et al.: The effects of hydroxyapatite

and platelet rich plasma on apexogenesis in monkeys

concentration of PRP is optimal for the processes of tissue reparation and regeneration (Han et al., 2007).

The aim of this study was to evaluate the effects of PRP in conjugation with HAP as pulp capping materials, to root and periodontium formation.

\section{MATERIALS AND METHODS}

Experimental animals

Eight young monkeys (Cercopithecus Aethiops) with the average body mass of 1500 gr., with permanent dentition and incomplete root formation, were involved in this study. The experiment was approved by the Ethical Committee of the Faculty of Stomatology. All experimental procedures were carried out in accordance with the European Community Directive (86/609/EEC), meaning that animals suffered no physical or mental pain, under conditions of asepsis and antisepsis, in a minimal required time (ISO-7405).

\section{Material used}

The following materials were used:

- Life ${ }^{\circledR}$, Kerr Co, Orange County, CA, USA (commercial calcium hydroxide),

- Apatec ${ }^{\circledR}$, Stomygen (commercial hydroxylapatite),

- PRP (prepared by Institute of Torlak).

\section{Experimental procedure}

The animals were anesthetized after premedication with atropine sulphate ( $0.5 \mathrm{mg} / \mathrm{kg}$ body weight) with an intramuscular injection of Conbern ${ }^{R}$ $(0.005 \mathrm{mg} / \mathrm{kg})$ Bayne, Germany and intravenous injection of Nembutal, Abbott Labs, Chicago USA ( $25 \mathrm{mg} / \mathrm{kg})$.

Intact teeth, first molars, canines and third incisors from both jaws were used. The teeth were isolated with cotton rolls, polished and washed with $0.5 \%$ chlohexidine. Buccal class V cavities were prepared by inverted cone carbide bur mean size 31, with an air turbine with sterile saline spray. The pulps were exposed with a round bur, producing a wound the size of the cutting edge of the bur. Following trepanation, the pulp was removed to the level of the cement-enamel junction (CEJ). The pulp lesion was capped with calcium hydroxide (Life ${ }^{\circledR}$, Kerr; control group; $n=10$ ), HAP (Apatec; experimental group I, EG I; $n=10$ ), and HAP in conjunction with autogenous PRP (experimental group II; EG II; $n=10$ ). The guidelines of the International Standard Organization (ISO 7405) require the established capping materials to be used as the control group for measuring pulp responses. Calcium hydroxide is commonly used as the control group because it is generally the most well established material (Stanley, 1968; Schroeder, 1985; Cox and Bergenholt, 1986; D'Souza et al., 1995). The material was placed at the exposure site and the cavities were immediately restored with amalgam. The observation period lasted for six months. After that the animals were scarified with an overdose of Nembutal ${ }^{R}$, the jaws were dissected and the tissue was fixed for light microscopy analysis. 


\section{PRP preparation}

PRP was prepared from the blood obtained from the experimental animals following the modified method developed by Weibrich et al. (2002). A total blood volume of $36.0 \mathrm{~mL}$ was centrifuged in the standard laboratory centrifuge (MSE, England) for $20 \mathrm{~min}$ at 1200 r.p.m.), with added anticoagulat Na-citrate. The sediment consisted of two areas: the upper 6-7 $\mathrm{mm}$, which is the area with the highest platelet concentration, and, beneathit, the area of blood cell elements. The extracted platelet concentrate was resuspended, and in a second step the platelet count was concentrated by further centrifugation (15 min. at 2000 r.p.m.) to adjust the final concentration of PRP. As a result, two clearly marked fractions appeared: the upper - serum with a few platelets, and the lower - concentrated platelets. After the serum was removed, the concentrated platelets were ready for application.

\section{Histological analysis}

The tissue for histological analysis was taken en block, containing experimental teeth with the surrounding bone. Teeth were collected following ISO usage guidelines (Technical Report 7405) 6 months after pulp exposure and capping. The material for histological analysis was fixed in $10 \%$ buffered formalin ( $\mathrm{pH} \mathrm{7.2)}$, demineralized for $40-50$ days in $5 \%$ trichloracetic acid and embedded in paraffin. Serial sections $6 \mu \mathrm{m}$ thick were cut in mesio/distal direction, mounted on glass slides, stained with haematoxylin and eosin, as well as with Gram for identification of bacteria, and analyzed microscopically (Carl Zeiss Inc., Oberkochen, Germany).

Histological analysis was performed according to the following criteria:

1. dentin bridge formation (thickness, localization, morphological aspects, continuity with surrounding dentin). The dentin bridge was identified as the formation of tertiary dentine by newly differentiated odontoblast-like cells, at the site of pulp exposure (Murray et al., 2003). Dentine bridge is a specialized type of reparative dentine secretion because it has a tubular continuity with the newly differentiated odontoblast-like cells. This is not the case with physiological secondary dentine or reactionary dentine, produced by original odontoblasts (Smith et al.,1995). Reactionary dentine, sometimes called irregular dentine, is identified as an area of increased tertiary dentine secretion with a tubular continuity with the physiological secondary dentine (Mjor, 1983). A differentiation between reactionary and reparative dentine was made during the examination of the sections.

2. morphological integrity of odontoblasts and odontoblast-like cells, as well as the integrity of deeper pulp tissue, according to criteria established by Murray et al. (2002; 2003), Cox et al. (1996), Tziafas (1994) and Mjor et al. (1991).

3. inflammatory response of each pulp (chronic or acute, intensity and localization). Inflammatory reaction was categorized in increasing order of severity from "none", "slight", and "moderate" to "severe", according to Federation Dentaire Internationale and International Organization for Standardization standards and published criteria (Mjor, 1983). The samples, in which the inflammatory reaction was scored as none, were characterized with either 
complete absence of inflammatory cells or presence of very few cells. Mild inflammation was present in samples in which inflammatory cells were observed just beneath the capping material. Moderate inflammation was observed in samples in which more than one third of the pulp tissue was infiltrated with inflammatory cells and severe inflammation was observed in samples in which dental pulp was diffusely infiltrated with mononuclear cells, with complete destruction of the normal histological organization of pulp tissue.

4. vascular reaction (stasis, dilatation and signs of neoangiogenesis)

5. presence of bacterial cells

6. complete root and periodontium formation.

\section{RESULTS}

Results of histological analysis in experimental samples

Dentin bridge formation, integrity of odontoblast-like cells and deeper pulp tissue

Results of the histological analysis revealed that the healing process in the dentin pulp complex resulted in dentin bridge formation in almost all samples in both experimental groups (in only two cases dentin bridge formation failed). Newly formed dentin possessed characteristics of reparative dentin, with a small number of irregularly positioned dentinal tubules, which appeared to be in continuity with the surrounding dentin (Figure 1).

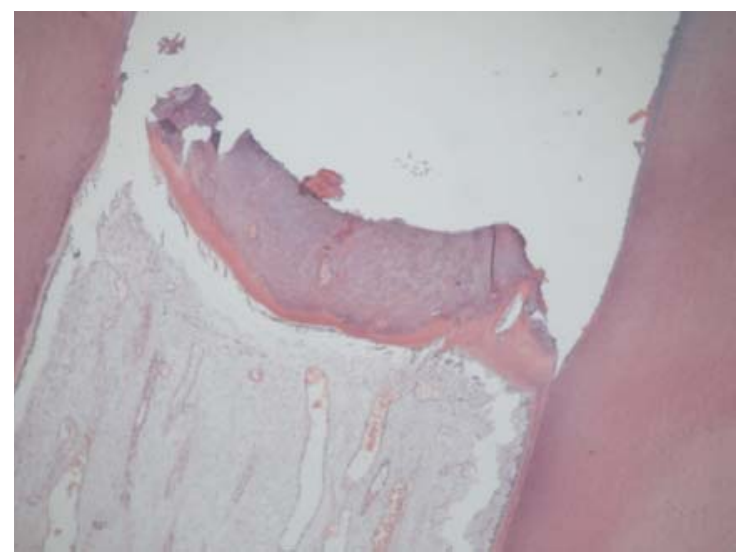

Figure 1. HE.40x. HAP/PRP. Dentin bridge covered the whole area of pulp exposure and achieved adhesion to surrounding dentin. This was considered as an acceptable therapeutic result, because it completely closed the pulp chamber thus preventing bacterial invasion

In four samples of EG I and eight samples of EG II the dentin bridge covered the whole area of exposed pulp, preventing microleakage and bacterial invasion, 
which was crucial for maintaining pulp integrity and providing the conditions for root formation. Beneath the dentin bridge formation odontoblast-like cells were identified. Great variations in the number of these cells were observed. These newly differentiated cells have a similar morphology to odontoblast cells, but with a tubular continuity with dentine bridge secretion. Original odontoblasts were positioned peripherally to the site of exposure. They were identified as primary pallisade columnar cells with an eosinophilic cytoplasm and a nucleus located in a basal position, adjacent to the predentine. As the characteristics of the healing processes in the dentin-pulp complex were described to be almost the same, or at least very similar in both experimental groups, it could be hypothesized that the material used for pulp capping had little influence on mechanisms by which reparative dentinogenesis occurred. The presence of odontoblast-like cells was found to be the most important factor influencing dentin bridge formation. Histological analysis of samples of EG I revealed smaller densities of these cells, compared to EG II. In the samples of EG I we were able to observe that small densities of odontoblast-like cells were associated with decreased dentine bridge formation. Opposite to this, the healing process in the dentin-pulp complex in EG II was characterized with a much greater number of odontoblast-like cells and more expressed dentin bridge width (Figure 2).

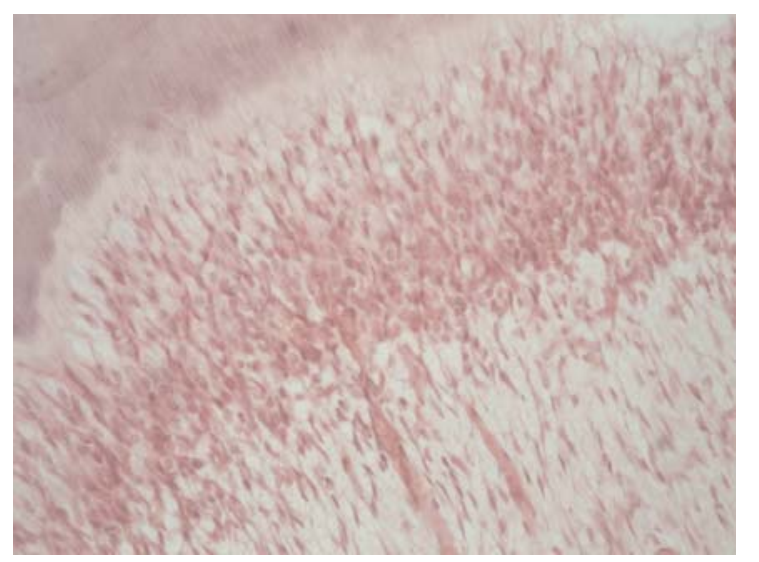

Figure 2. HE.400x. HAP/PRP. Increased number of odontoblast-like cells in EG II suggesting that PRP has influence to odontoblast-like cell proliferation and differentiation

Based on this observation it could be presumed that growth factors from PRP have an influence on cell proliferation and differentiation. Bacterial microleakage appeared to have an effect on the density of odontoblast-like cells.

The results of microscopic analysis revealed that the subjacent pulp tissue underwent reorganization process as well. Reorganizing tissue comprised of a mixed range of cells with differing morphologies, including fibroblasts and inflammatory cells. Reorganization of the subjacent area was correlated with the 
number of odontoblast-like cells and it was more prominent in EG II. Although the role of the subjacent area cells remains unclear, it could be presumed that these cells have a supporting function in relation to odontoblast-like cells.

\section{Inflammatory reaction, presence of bacteria and vascular reaction}

Chronic inflammatory reaction occurred in eight samples of group EGI and seven samples in EG II, with variable intensity and extension. Most of the analyzed samples had slight or moderate inflammation. The rest of the samples were characterized by an absence of inflammatory cells. Severe chronic inflammation nor massive infiltration of neutrophils with abscess formation was identified in none of the samples.

The Gram stain method showed a small number of Gram positive cocci in the dentinal tubules beneath the capping material in two cases in EG I and three cases in EGII. It could be difficult to explain whether these bacteria invaded the dentin during the capping procedure, or whether they came into dentinal tubules through the cavity margins later on, during the healing process, due to microleakage of the restorative material.

In all samples of EG I and six samples of EG II, signs of neoangiogenesis with proliferation and formation of new blood vessels were observed, suggesting that the healing process was accompanied with complete revascularization. This observation could be considered as one of the major parameters of pulp repair and remodellation (Figure 3).

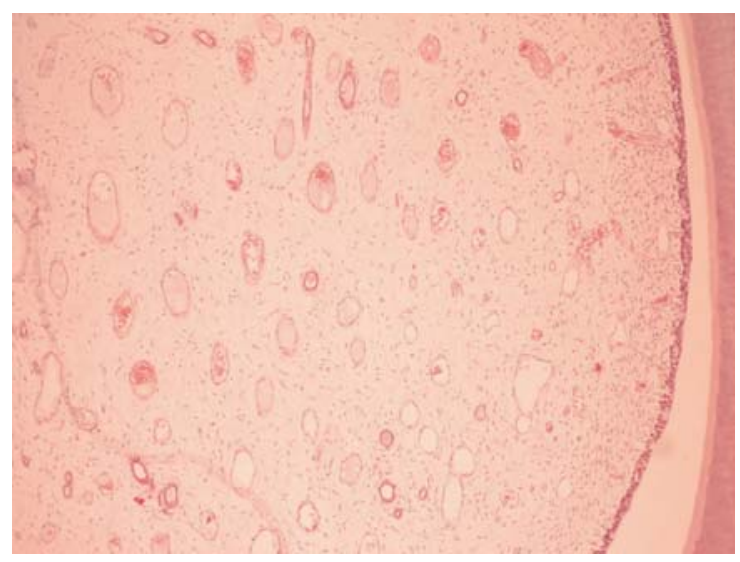

Figure 3. HE.100x. HAP. The absence of inflammatory cells infiltrates suggested the biocompatibility of the applied material. The newly formed blood vessels were observed in dental pulp, indicating that revascularization and remodellation of pulp tissue occurred

In eight samples of EG I and nine samples of EG II, histological characteristics of the apical periodontium suggested that apexogenesis was in 
the terminal stages (Figure 4). As it was expected, apexification was observed in not even one sample.

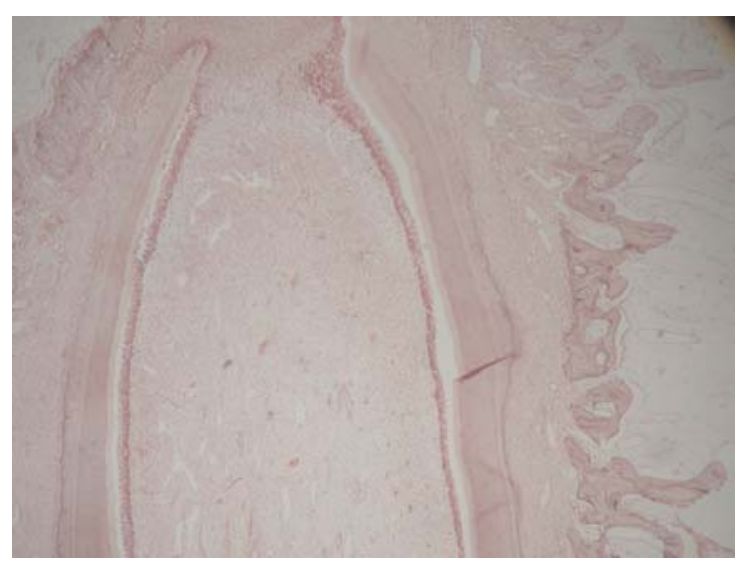

Figure 4. HE. 40x. HAP/PRP. Terminal stages of root and surrounding periodontium formation

Results of the histological analysis in control samples

Results of the histological analysis of the control group revealed that six months after pulp exposure and capping with calcium hydroxide the healing process was uncomplicated and characterized by dentin bridge formation in six samples. In four control group samples the dentin bridge provided complete closure of the pulp chamber. In the rest of the samples, the dentin bridge was incomplete and could provide only partial closure of the pulp chamber. Dentin bridge was characterized by the presence of calcium hydroxide particles and connective tissue components. In two samples tunnel defects, infiltration with connective tissue were observed.

In eight samples the pulp structure was disturbed, especially just beneath the dentin bridge. The changes of the pulp structure varied from minimal to very severe and affected all pulp zones. The central zone of the pulp was characterized by the presence of stasis, hemorrhage and inflammation (Figure 5).

In all analyzed samples mononuclear cells were observed in the dental pulp, suggesting the presence of chronic inflammation, which was scored from mild to moderate, according to previously established criteria. Unexpectedly, inflammatory cells were more numerous in the central, than in peripheral parts of the pulp and were not related to the presence of bacterial cells. Bacteria were identified in the dentinal tubules in five samples, while no bacteria were identified in the dental pulp.

In six analyzed control samples it was observed that dental root formation was completed. In nine samples an uncalcified connective tissue barrier was observed, which prevented communication between the dental pulp and surrounding periodontium. 
Acta Veterinaria (Beograd), Vol. 59. No. 2-3, 277-289, 2009.

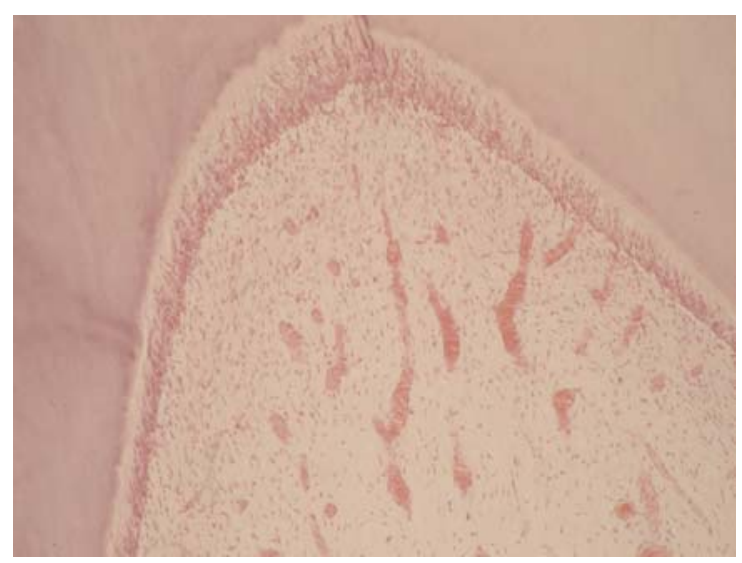

Figure 5. HE. 100x. Control. Vasodilatation and stasis in the central part of the pulp of the control group. This finding was probably related to the chemical properties of the capping material and mechanical trauma during cavity preparation, rather than the presence of bacterial infection

\section{DISCUSSION}

The results of our study revealed that healing of the artificially created defects in the dentine-pulp complex was uneventful in both experimental groups, as well as in the control group. Neither abscesses nor necrosis of the pulp occurred, which was expected due to aseptic conditions in the operative field. As a favorable treatment result we considered the one in which: a) morphological and functional integrity of the pulp was maintained by the closure of the pulp chamber by dentinal bridge, formed by the process of reparatory dentinogenesis, and b) completion of root formation followed by appropriate development of the apical periodontium. The described result was achieved in both experimental groups, and in the control group, which suggests that the capping material is of secondary importance, pointing out the importance of the integrity of the pulp, especially odontoblasts or odontoblast-like cells, as well as the absence of infection and necrosis, which is agreement with the results reported by Murray et al. (2003).

In our study it was shown that the density of odontoblasts was of greatest importance for reparatory dentinogenesis. Specimens with the highest cell density were those in which reparatory bridges were thicker and with higher structural regularity. We can hypothesize that PRP have an influence on odontoblast proliferation and differentiation. There are few data on the mitogenic effect of PRP on odontoblasts. On the other hand, it is well established that PRP is mitogenic for a variety of cell types, including bone cells from human adults (Gruber et al., 2002), rat bone marrow-derived cells (Oprea et al., 2003), human mesenchymal progenitor cells (Lucarelli et al., 2003), endothelial cells (Veis, 1985), and human osteosarcoma lines HOS and SaOS-2 (Mjor et al., 1991). 
Veis (1985) found that odontoblast-like cells require adhesion to an appropriate surface before cell differentiation and dentin bridge formation. It was recently found that PRP stimulates mesenchimal periodontal ligament cells adhesion and proliferation (Froum et al., 2002). It can be expected that PRP has a similar effect on odontoblasts, stimulating reparatory dentonogenesis in that way. Results of our study revealed that higher densities of odontoblasts were associated with higher structural regularity in the organization of subodontoblastic layers of dental pulp and increased number of cells, mainly fibroblasts. This observation was in agreement with results reported by Mjor et al. (1991).

Our study was not strictly addressed to the mechanisms by which odontoblast-like cell differentiation and reparative dentinogenesis take place leading to dentin bridge formation. Results from the previous studies showed that growth factors, particularly TGF- $\beta$, stimulate odontoblast's differentiation, and lead to the release of endogenous growth factors from the organic matrix of dentin, which additionally stimulates dentinogenesis (Tzifas, 1994).

Absence of inflammatory infiltrate cells is one of the most important parameters of the biocompatibility of the applied material in vivo (Costa et al., 2003). In the most of our specimens from both experimental groups and from the control group inflammatory cells were not observed or their number was minimal. This finding is suggesting high biocompatibility of the materials applied in our study.

Results of analyzed sections revealed that in most of the studied samples the roots and surrounding periodontium terminated their development. There are numerous data concerning the influence of growth factors on periodontal reparation and regeneration (Regan et al., 1999; Nakamura et al., 2003). The design of our study does not allow us to conclude if growth factors were the most responsible for such favorable result concerning completion of root and periodontium. We hypothesize that it was, rather, due to intact Hertwig's epithelial sheath, as well as due to the absence of infection and inflammation.

It can be concluded that wound healing in the pulp-dentin complex in both experimental groups and in the control group was characterized by the formation of dentinal bridges, due to uneventful reparatory dentinogenesis, by preservation of morphological and functional integrity of the pulp, and by completion of root and surrounding periodontium development. Microscopic analysis revealed better results in the HAP/PRP group, which leads to the conclusion that HAP/PRP as pulp capping material is a superior alternative to HAP or calcium hydroxide alone.

\footnotetext{
Address for correspondence: Dr Vanja Petrović

Clinic of Pedriatic Dentistry

Faculty of Stomatology,

Dr Subotića 8, 11000 Belgrade

E-mail: vanja65@hotmail.com
} 


\section{REFERENCES}

1. Alliot-Licht B, Hurtlel D, Gregoire M, 2001, Characterization of smooth muscle actin positive cells in mineralized human dental pulp cultures, Arch Oral Biol, 46, 221-8.

2. Andreasen JO, 1994, Apexogenesis, In: Andreasen JO, Andreasen FM (ed), Textbook and color atlas of traumatic injuries to the teeth, 3rd ed. Munksgaard, Copenhagen, 63-5.

3. Andreasen JO, Borum MK, Andreasen FM, 1992, Replantation of 400 avulsed permanent incisors, Endod Dent Traumatol, 8, 45-55.

4. Costa C A S, Oliveira M F, Giro E M A, Hebling J, 2003, Biocompatibility of resin-based materials used as pulp-capping agents, Int Endodont J, 36, 12, 831-9.

5. Cox CF, Bergenholt G, 1986, Healing sequence in capped inflamed pulps of Rhesus monkeys (Macaca mulatta), Int Endodont J, 19,113-20.

6. Cox CF, Sübay RK, Ostro E, Suzuki S, 1996, Tunnel defects in dentin bridges: their formation following direct pulp capping, Operat Dent, 21, 4-11.

7. D'Souza RN, Bachman T, Baumgardner KR, Butler WT, Litz M, 1995, Characterization of cellular responses involved in reparative dentinogenesis in rat molars, $J$ Dent Res, 74, 702-9.

8. Froum SJ, Wallace SS, Tarnow DP, Cho SC, 2002, Effect of platelet-rich plasma on bone growth and osseointegration in human maxillary sinus grafts: three bilateral case reports, Int $J$ Periodont Rest Dent, 22, 45-53.

9. Gentry PA, 1992, The mammalian blood platelet: its role in haemostasis: inflammation and tissue repair, J Comp Pathol, 107, 243-70.

10. Graziani F, Ivanovski S, Cei S, Ducci F, Tonetti M, Gabriele M, 2006, The in vitro effect of different PRP concentrations on osteoblasts and fibroblasts, Clin Oral Imp Res, 17, 2, 212-9.

11. Gronthos S, Brahim J, Li W, 2002, Stem cell properties of human dental pulp stem cells, J Dent Res, 81, 531-5.

12. Gruber R, Varga F, Fischer MB, Watzek G, 2002, Platelets stimulate proliferation of bone cells: involvement of platelet-derived growth factor, microparticles and membranes, Clin Oral Imp Res, 13, 529-35.

13. ISO-7405, 1997, Preclinical evaluation of biocompatibility of medical devices used in dentistry, test methods for dental materials, International Organization for Standartization - ISO E, 1-18.

14. Han HX, Meng J M, Tang S L, Li Y, Tang Z, Chen B, 2007, The effect of different platelet-rich plasma concentrations on proliferation and differentiation of human periodontal ligament cells in vitro, Cell Prolif, 40, 2, 241-52.

15. Kanno T, Takahashi T, Tsujisawa T, Ariyoshi W, Nishihara T, 2005, Platelet-rich plasma enhances human osteoblast-like cell proliferation and differentiation, Int J Oral Maxillofac Surg, 63, 362-9.

16. Kilian O, Flesch I, Wenisch S, Taborski B, Jork A, Schnettler R, Jonuleit T, 2004, Effects of platelet growth factors on human mesenchymal stem cells and human endothelial cells in vitro, Eur $J$ Med Res, 9, 337-44.

17. Kim SG, Chung CH, Kim YK, Park JC, Lim SC, 2002, Use of particulate dentin-plaster of Paris combination with/without platelet-rich plasma in the treatment of bone defects around implants, Int J Oral Maxillofac Imp,17, 86-94.

18. Lucarelli E, Beccheroni A, Donati D, Sangiorgi L, Cenacchi A, Del Vento AM, Meotti C et al, 2003, Platelet-derived growth factors enhance proliferation of human stromal stem cells, Biomaterials, 24, 3095-100.

19. Mazor Z, Peleg M, Garg AK, Luboshitz J, 2004, Platelet-rich plasma for bone graft enhancement in sinus floor augmentation with simultaneous implant placement: patient series study, Imp Dent, $13,65-72$

20. Mjör IA, 1983, Biological and clinical properties. In: Mjör IA, ed. Dental Materials, Biological Properties and Clinical Evaluation, CRC Press, Bocca Raton, 91-121.

21. Mjör IA, Dahl E, Cox CF, 1991, Healing of pulp exposures: an ultrastructural study, J Oral Pathol, 20, 496-501.

22. Murray PE, Hafez AA, Smith AJ, Cox CF, 2002, Hierarchy of pulp capping and repair activities responsible for dentin bridge formation, $A m J$ Dent, 15, 236-43. 
23. Murray PE, Hafez AA, Smith AJ, Windsor LJ, Cox CF, 2003, Histomorphometric analysis of odontoblast-like cell numbers and dentine bridge secretory activity following pulp exposure, Int Endodont J, 36, 2, 106-16.

24. Murray PE, Hafez AA, Smith AJ, Windsor LJ, Cox CF, 2003, Histomorphometric analysis of odontoblast-like cell numbers and dentine bridge secretory activity following pulp exposure, Int Endodont J, 36, $106-16$.

25. Nakamura T, Yamamoto, M, Tamura, M, Izumi, Y, 2003, Effects of growth/differentiation factor-5 on human periodontal ligament cells, J Periodont Res, 38, 6, 597-605.

26. Oprea WE, Karp JM, Hosseini MM, Davies JE, 2003, Effect of platelet releasate on bone cell migration and recruitment in vitro, J Craniofac Surg, 14, 292-300.

27. Rafter M, 2005, Apexification: a review. Dent Traumatol, 21, 1-8.

28. Regan J D, Gutmann J L, lacopino A M, Diekwisch T, 1999, Response of periradicular tissues to growth factors introduced into the surgical site in the root-end filling material, Int Endodont $\mathrm{J}$, $32,3,171-82$

29. Schroeder $U, 1985$, Effects of calcium hydroxide-containing pulp capping agents on pulp cell migration, proliferation and differentiation, J Dent Res, 64, 541-8.

30. Smith AJ, 2002, Dentin formation and repair, In Hargreaves KM, Goodis HE, (ed) Seltzer and Bender's Dental Pulp, Chapter 3, 3rd ed, Quintessence Publishing Co, Chicago, 41-62.

31. Stanley HR, 1968, Design for a human pulp study. Part II, Oral Surg Oral Med Oral Pathol, 25, 75664.

32.. Tzifas D, 1994, Mechanisms controlling secondary initiation of dentinogenesis: a review, Int Endodont J, 27, 61-74.

33. Veis $A, 1985$, The role of the dental pulp thoughts on the session of pulp repair responses, J Dent Res, 64, 552-4.

34. Webber RT, 1984, Apexogenesis versus apexification, Dent Clin N Am, 28, 669-97.

35. Weibrich G, Wilfried K, Kleis G, Curasan M, 2002, PRP kit vs. PCCS PRP system. Collection efficiency and platelet counts of two different methods for the preparation of platelet-rich plasma, Clin Oral Imp Res, 13, 4, 437-43.

\title{
UTICAJ HIDROKSIAPATITA I PLAZME BOGATE TROMBOCITIMA NA PROCES APEKSOGENEZE KOD MAJMUNA
}

\author{
PETROVIĆ VANJA, DANILOVIĆ VESNA, MARKOVIĆ DEJAN, ČAKIĆ SAŠA, \\ KRSTIĆ NIKOLA i MARKOVIĆ DANICA
}

\section{SADRŽAJ}

Podaci iz literature o primeni faktora rasta u vitalnoj terapiji pulpe su oskudni i često kontraverzni. Cilj našeg rada je bio da se ispita uticaj plazme bogate trombocitima u kombinaciji sa hidroksiapatitom, kao materijala za direktno prekrivanje pulpe, na završetak rasta korena i formiranje okolnog parodoncijuma. Istraživanje je sprovedeno na osam mladih majmuna (Cercopithecus aethiops), sa stalnom denticijom i nezavršenim rastom korena. Nakon pulpotomije, pulpna lezija je prekrivena kalcijum hidroksidom (kontolna grupa), hidroksiapatitom (eksperimentalna grupa I) ili hidroksiapatitom u kombinaciji sa plazmom bogatom trombocitima (eksperimentalna grupa II). Šest meseci kasnije životinje su žrtvovane, a uzeto tkivo pripremljeno je za histološku analizu. Rezultati histološke analize uka- 
Acta Veterinaria (Beograd), Vol. 59. No. 2-3, 277-289, 2009.

Petrović Vanja et al.: The effects of hydroxyapatite

and platelet rich plasma on apexogenesis in monkeys

zali su da je zarastanje bilo karakterisano stvaranjem mineralizovanog dentinskog mostića, uz očuvanje morfološkog i funkcionalnog integriteta pulpe i završetak rasta korena i okolnog parodoncijuma u uzorcima svih ispitivanih grupa. Zapaljenska reakcija je gotovo u svim ispitivnim uzorcima bila ocenjena kao blaga ili umerena, što govori u prilog biokompatibilnosti primenjenih materijala. Na osnovu dobijenih rezultata može se reći da su svi primenjeni materijali pogodni za direktno prekrivanje pulpe, da doprinose očuvanju integriteta pulpe i ubrzavaju završetak rasta korena i formiranje apikalnog parodoncijuma, s tim što hidroksipatit u kombinaciji sa endogenim faktorima rasta predstavlja superiorniju alternativu u odnosu na druge materijale korišćene u ovoj studiji. 